Jurnal Ilmu Ekonomi \& Sosial, Vol.11, No.2, Oktober 2020; 92 - 101

p-ISSN: 2085-8779 e-ISSN: 2354-7723

http://ejournal.unmus.ac.id/index.php/ekosos

DOI : $10.35724 /$ jies.v11i2.2754

\title{
Likuiditas, Profitabilitas Dan Nilai Perusahaan
}

\author{
Andi Hidayat, Muhammad Nurhadi Nuhung. \\ Sekolah Tinggi Ilmu Ekonomi (STIE) AMKOP Makassar \\ email: yayatdesta@gmail.com,
}

\begin{abstract}
ABSTRAK
Penelitian ini bertujuan untuk menguji pengaruh likuiditas dan profitabilitas terhadap nilai perusahaan pada perusahaan Properti, Real Estate dan Konstruksi Bangunan yang terdaftar di LQ45 Periode 2015-2018. Sampel penelitian menggunakan metode purposive sampling dan diperoleh 6 perusahaan yang akan dijadikan objek penelitian. Metode analisis yang digunakan yaitu analisis regresi linear berganda. Hasil penelitian menunjukkan bahwa secara parsial variabel likuiditas (X1) tidak berpengaruh terhadap nilai perusahaan $(Y)$ dan variabel profitabilitas (X2) berpengaruh positif signifikan terhadap nilai perusahaan (Y). Koefisien regresi untuk variabel likuiditas yang menunjukan hubungan negatif mengindikasikan bahwa adanya modal kerja yang cukup, memungkinkan bagi perusahaan untuk beroperasi secara maksimal dan tidak mengalami kesulitan akibat krisis keuangan, akan tetapi modal kerja yang berlebihan juga memberikan dampak yang kurang baik bagi perusahaan dimana hal ini menunjukkan terdapat dana yang tidak produktif, sehingga dana kas yang ada pada perusahaan harus berada pada titik yang optimal
\end{abstract}

Kata Kunci: Likuiditas; Profitabilitas; Nilai Perusahaan.

\begin{abstract}
This study aims to examine the effect of liquidity and profitability on firm value in Property, Real Estate, and Building Construction Companies listed in LQ45 for the 2015-2018 period. The research sample uses purposive sampling method and obtained 6 companies that will be the object of research. The analytical method used is multiple linear regression analysis. The results showed that partially the liquidity variable (X1) did not affect firm value (Y) and profitability variable (X2) had a significant positive effect on firm value $(Y)$. The regression coefficient for the liquidity variable which shows a negative relationship indicates that there is sufficient working capital, allowing the company to operate optimally and not experience difficulties due to the financial crisis, but excessive working capital also has an adverse impact on the company where this shows that there is unproductive funds, so that cash funds in the company should at an optimal point
\end{abstract}

Keywords: Liquidity; Profitability; Firm Value.

\section{PENDAHULUAN}

Angka pertumbuhan penduduk di Indonesia yang cukup tinggi setiap tahunnya, menyebabkan tingginya peningkatan terhadap kebutuhan akan tempat tinggal, sarana perkantoran, sarana perbelanjaan dan tempat publik lainnya. Seiring dengan peningkatan kebutuhan tersebut, kemudian menjadi sebuah potensi pasar yang menjanjikan atas permintaan produk property yang semakin tinggi. Pada satu sisi permintaan produk property meningkat, namun di sisi yang lain ketersediaan lahan untuk pembangunan sangat terbatas sehingga membuat harga tanah menjadi tinggi dari tahun ke tahun. Sementara itu, bunga pinjaman untuk modal kerja atau perolehan produk property juga ikut tinggi. Dari 
hal tersebut, banyak investor yang kemudian melakukan investasi dalam bentuk tanah dan property.

Tujuan utama perusahaan adalah untuk meningkatkan kemakmuran pemilik perusahaan melalui peningkatan nilai perusahaan. Nilai perusahaan akan meningkat apabila harga saham meningkat yang ditandai dengan tingkat pengembalian investasi yang tinggi kepada pemegang saham. Nilai perusahaan dapat diukur melalui beberapa cara, salah satunya adalah dengan melakukan analisis terhadap rasio keuangan. Analisis rasio keuangan yang bisa dilakukan para investor diantaranya adalah rasio likuiditas, rasio solvabilitas, rasio profitabilitas dan rasio aktivitas [1]. Dari keempat rasio yang tersedia, penelitian ini hanya focus pada dua yaitu rasio likuiditas dan rasio profitabilitas.

Suatu perusahaan dapat dikatakan berhasil dalam kegiatan usahanya apabila secara berkelanjutan mampu memperoleh laba serta dapat memenuhi kewajiban finansial yang harus segera dibayar. Laba yang diperoleh setiap periode merupakan syarat utama dalam menjamin kelangsungan hidup suatu perusahaan. Dengan kata lain, perusahaan harus dapat memperhatikan aspek likuditas dan aspek profitabilitas mereka agar usaha tersebut dapat bertahan dan memberi kemakmuran bagi pemiliknya.

Likuiditas mempunyai hubungan yang cukup erat dengan kemampuan perusahaan memperoleh laba (profitable), karena likuiditas menunjukkan tingkat ketersediaan modal kerja yang dibutuhkan dalam aktivitas operasional. Adanya modal kerja yang cukup, memungkinkan bagi perusahaan untuk beroperasi secara maksimal dan tidak mengalami kesulitan akibat krisis keuangan. Akan tetapi, modal kerja yang berlebihan juga memberikan dampak yang kurang baik bagi perusahaan karena dengan modal kerja berlebihan akan menunjukkan bahwa terdapat dana yang tidak produktif. Modal kerja yang tidak produktif tersebut dapat memberikan kesan kepada stakeholder bahwa perusahaan melepaskan potensi keuntungan yang dapat diperolehnya melalui berbagai investasi produktif yang dapat dilakukan. Secara ideal, modal kerja perusahaan seharusnya tersedia dalam jumlah yang cukup untuk membiayai berbagai kegiatan perusahaan. Hal ini berarti, modal kerja yang dimiliki tidak dalam kondisi yang kurang dan juga tidak dalam kondisi yang berlebihan. Dengan demikian, kemampuan perusahaan menghasilkan laba atas aktiva yang dimiliki menjadi maksimal.

Rasio likuiditas digunakan untuk mengambarkan seberapa likuidnya suatu perusahaan serta kemampuan perusahaan untuk menyelesaikan kewajiban jangka pendek dengan menggunakan aktiva lancar. Dengan kata lain, rasio ini digunakan untuk mengukur kemampuan perusahaan dalam membayar kewajiban yang segera jatuh tempo [2]. Rasio likuiditas memberikan cukup banyak manfaat bagi berbagai pihak di perusahaan. Likuiditas 
Jurnal Ilmu Ekonomi \& Sosial, Vol.11, No.2, Oktober 2020; 92 - 101

p-ISSN: 2085-8779 e-ISSN: 2354-7723

http://ejournal.unmus.ac.id/index.php/ekosos

DOI : $10.35724 /$ jies.v11i2.2754

merupakan kemampuan untuk mengubah aktiva menjadi kas atau kemampuan untuk memperoleh kas [3]. Selain sebagai nilai yang mencerminkan kemampuan perusahaan dalam menyelesaikan kewajiban jangka pendeknya, likuiditas pada perusahaan juga memberikan gambaran terkait dengan kemampuan mereka dalam memperoleh kas.

Selain dari tingkat likuiditas perusahaan, profitabilitas perusahaan juga menjadi cukup penting untuk diperhatikan baik oleh pihak manajemen ataupun oleh investor karena nilai ini mampu menggambarkan hubungan antara laba yang dihasilkan oleh perusahaan dengan aktiva yang dimilikinya. Profitabilitas merupakan rasio keuangan yang menunjukkan perbandingan antara laba dengan aktiva atau modal yang menghasilkan laba tersebut [4]. Rasio profitabilitas terdiri atas dua jenis, yaitu rasio yang menunjukkan profitabilitas dalam kaitannya dengan penjualan, serta rasio yang menunjukkan profitabilitas dalam kaitannya dengan investasi [5]. Profitabilitas dalam hubungannya dengan penjualan terdiri atas margin laba kotor (gross profit margin) dan margin laba bersih (net profit margin). Profitabilitas dalam hubungannya dengan investasi terdiri atas tingkat pengembalian terhadap aktiva (return on total assets) dan tingkat pengembalian terhadap ekuitas (return on equity).

Dalam menjaga kelangsungan hidup dan kontinuitas perusahaan termasuk perusahaan property dan real estate, diperlukan upaya dalam mengelola kebijaksanaan keuangan dengan baik. Pengelolaan keuangan yang baik dapat tercermin melalui kemampuan perusahaan dalam memenuhi kewajiban mereka yang jatuh tempo serta kemampuan perusahaan dalam menghasilkan keuntungan. Namun seiring jalannya aktivitas operasional, perusahaan kadang kurang mampu menjaga keselarasan dari dua hal tersebut yaitu posisi likuditas yang tidak memadai sebagai akibat dari orientasi perusahaan yang terlalu mengejar keuntungan tanpa mengimbangi pengelolaan aspek likuiditas atau karena perusahaan terlalu memperhatikan aspek likuiditas sehingga profitabilitasnya menurun [6].

\section{METODE}

Penelitian yang bersifat kuantitatif yang digolongkan pada kelompok data digunakan selama periode lima tahun ini merupakan penelitian kausal komparatif dimana akan menggambarkan hubungan sebab akibat antara dua variabel atau lebih [7]. Dengan menggunakan data sekunder yang diperoleh dari Bursa Efek Indonesia dengan periode penelitian dari tahun 2015-2018. dilakukan analisis atas variabel likuiditas dan variabel profitabilitas terhadap nilai perusahaan. Adapun sampel yang digunakan adalah kuantitatif yang diukur dalam suatu skala numeric, berupa data laporan keuangan tahunan dan 
laporan keuangan yang telah dipublikasikan. Masing-masing perusahaan tersebut yaitu PT Adhi Karya Tbk., PT Bumi Serpong Damai, Tbk., PT Pembangunan Perumahan, Tbk., PT Pakuwon Jati, Tbk., PT Wijaya Karya, Tbk., dan PT Waskita Karya, Tbk.

Analisis data dilakukan dengan menggunakan analisis regrsi linear berganda yang dioperasikan melalui program software SPSS 23. Model analisis ini dipilih karena digunakan untuk melakukan analisa antara dua atau lebih variabel independen terhadap variabel dependen. Model yang digunakan dalam persamaan analisis regresi linear berganda, adalah sebagai berikut:

$\mathrm{Y}=\mathrm{a}+\mathrm{b} 1 \mathrm{X} 1+\mathrm{b} 2 \mathrm{X} 2+\mathrm{e}$

Keterangan:

$$
\begin{array}{ll}
\mathrm{Y} & =\text { Nilai Perusahaan } \\
\mathrm{a} & =\text { Konstanta } \\
\mathrm{b} 1, \mathrm{~b} 2 & =\text { Koefisien Regresi } \\
\mathrm{X} 1 & =\text { Likuiditas Perusahaan } \\
\mathrm{X} 2 & =\text { Profitabilitas Perusahaan } \\
\mathrm{e} & =\text { Error Term }
\end{array}
$$

\section{HASIL DAN PEMBAHASAN}

\section{A. Hasil}

Analisis Regresi Linear Berganda yang digunakan untuk mengetahui ada tidaknya pengaruh antara variabel bebas yaitu likuiditas (X1) dan profitabilitas (X2) terhadap variabel terikat yaitu nilai perusahaan $(\mathrm{Y})$ pada perusahaan properti, real estate dan konstruksi bangunan yang terdaftar di LQ45 periode 2015-2018

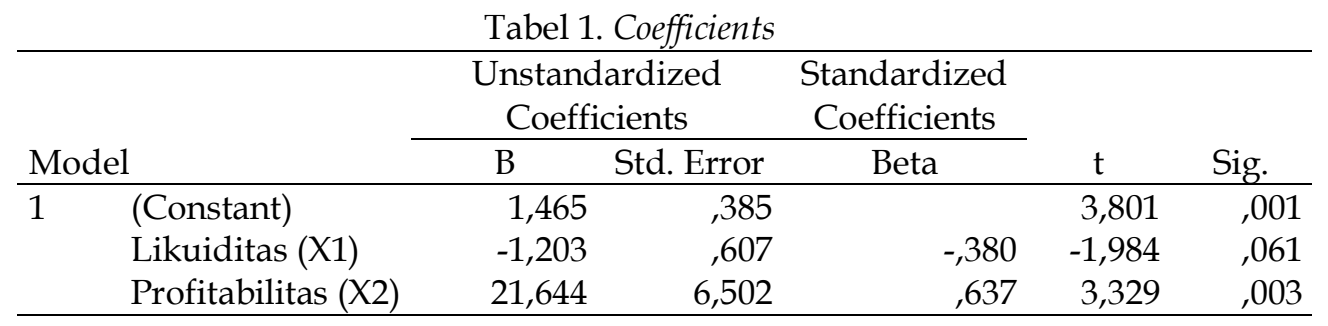

Sebagimana yang ditunjukan table 3, dapat dirumuskan dalam formulasi

$$
\mathrm{Y}=1,465-1,203 \mathrm{X} 1+21,644 \mathrm{X} 2+\mathrm{e}
$$

Persamaan regresi tersebut, dapat menjelaskan bahwa :

1) Nilai constant sebesar 1,465 yang berarti bahwa jika variabel likuiditas dan variabel profitabilitas bernilai tetap atau sama dengan nol maka nilai perusahaan bernilai 1,465 . 
Jurnal Ilmu Ekonomi \& Sosial, Vol.11, No.2, Oktober 2020; 92 - 101

p-ISSN: 2085-8779 e-ISSN: 2354-7723

http://ejournal.unmus.ac.id/index.php/ekosos

DOI : $10.35724 /$ jies.v11i2.2754

2) Koefisien regresi untuk variabel likuiditas adalah sebesar -1,203 yang berarti bahwa jika variabel likuiditas meningkat satu satuan dengan asumsi variabel profitabilitas dianggap konstan, maka nilai perusahaan akan turun sebesar 1,203 .

3) Koefisien regresi untuk variabel profitabilitas adalah sebesar 21,644 yang berarti bahwa jika variabel profitabilitas meningkat satu satuan dengan asumsi variabel likuiditas dianggap konstan, maka nilai perusahaan akan meningkat sebesar 21,644.

Analisis Koefisien Determinasi (R2) guna mengukur seberapa jauh kemampuan model dalam menerangkan variabel terikat.

Tabel 1. Model Summary

\begin{tabular}{|c|c|c|c|c|c|}
\hline Model & $\mathrm{R}$ & R Square & $\begin{array}{l}\text { Adjusted R } \\
\text { Square }\end{array}$ & $\begin{array}{l}\text { Std. Error of } \\
\text { the Estimate }\end{array}$ & $\begin{array}{l}\text { Durbin- } \\
\text { Watson }\end{array}$ \\
\hline 1 &, $596^{a}$ & ,355 & 294 & 83201 & 1,971 \\
\hline
\end{tabular}

Berdasarkan data pada table 2 (model summary), diperoleh hasil perhitungan untuk nilai R2 adalah sebesar 0,294 atau 29,4\%. Hal ini dapat diinterpretasikan bahwa variabel bebas yaitu likuiditas dan profitabilitas memberikan pengaruh terhadap nilai perusahaan sebesar $29,4 \%$, sedangkan sisanya sebesar $70,6 \%$ dipengaruhi oleh variabel di luar dari penelitian ini.

Dalam membuktikan hipotesis yang diajukan sebelumnya untuk hipotesis 1 dan 2, maka dilakukan uji $\mathrm{t}$ sebagai bentuk pengujian hipotesis dengan menggunakan taraf signifikansi sebesar 0,05. Kriteria yang diajukan adalah jika t-hitung < t-tabel, maka H0 diterima dan Ha ditolak. Namun, jika t-hitung > t-tabel maka H0 ditolak dan Ha diterima. Dari hasil analisis diperoleh data berdasarkan pada table 1 (coefficients), yaitu:

1) Likuiditas pada penelitian ini dengan mengacu pada table coefficients mempunyai tingkat signifikansi sebesar 0,061 yang lebih besar dari standard signifikansi yang diajukan yaitu sebesar 0,05 dan nilai t-hitung sebesar -1,984 dengan t-tabel sebesar -2,079 yang berarti nilai t-hitung < t-tabel. Hal ini berarti, bahwa H0 diterima dan H1 ditolak. Dari hasil ini kemudian dapat disimpulkan bahwa likuiditas perusahaan tidak mempunyai pengaruh terhadap nilai perusahaan. 
2) Profitabilitas pada penelitian ini yang mengacu pada table coefficents memiliki tingkat signifikansi sebesar 0,003 $<0,05$ dan nilai t-hitung sebesar 3,329 dengan t-tabel sebesar 2,079 yang berarti nilai t-hitung > t-tabel. Hal ini berarti, bahwa $\mathrm{H} 0$ ditolak dan $\mathrm{H} 2$ diterima. Hasil ini menunjukan bahwa profitabilitas perusahaan berpengaruh positif signifikan terhadap nilai perusahaan

Pembuktian hipotesis ketiga pada hipotesis yang diajukan sebelumnya, menggunakan uji F pada taraf signifikansi sebesar 0,05. Kriteria yang diajukan adalah jika Fhitung < F-tabel maka H0 diterima dan H3 ditolak. Namun, jika F-hitung > F-tabel maka H0 ditolak dan $\mathrm{H} 3$ diterima. Hasil analisis diperoleh sebagai berikut:

Tabel 3. Anova

\begin{tabular}{llrrrrr}
\hline Model & & Sum of & & & & \\
\hline 1 & Regression & 8,012 & & & & \\
& Squares & & Mean Square & F & \multicolumn{1}{c}{ Sig. } \\
& Residual & 14,537 & 21 & 4,006 & 5,787 &, $010^{\mathrm{b}}$ \\
& Total & 22,549 & 23 &, 692 & & \\
\hline
\end{tabular}

Dari table anova tersebut, diperoleh nilai $\mathrm{F}$ sebesar 5,787 dengan nilai signifikansi sebesar 0,010. Nilai perolehan F dari hasil analisis menunjukkan F-hitung > F-tabel yaitu 5,787 > 3,47 dan nilai signifikansi menunjukkan 0,010<0,05. Hal ini menunjukkan bahwa H0 ditolak dan H3 diterima. Dengan demikian dapat disimpulkan bahwa likuiditas dan profitabilitas berpengaruh secara simultan terhadap nilai perusahaan.

\section{B. Pembahasan}

\section{Pengaruh likuiditas terhadap nilai perusahaan.}

Pengujian statistic menunjukkan hasil nilai signifikansi untuk variabel likuiditas adalah sebesar 0,061 $>0,05$ dengan nilai t-hitung sebesar $-1,984<\mathrm{t}$-tabel $-2,079$. Hal ini berarti bahwa likuiditas perusahaan tidak berpengaruh terhadap nilai perusahaan pada perusahaan Properti, Real Estate dan Konstruksi Bangunan yang terdaftar di LQ45 periode 2015-2018.

Likuiditas perusahaan yang diproksikan melalui cash ratio menunjukkan kemampuan perusahaan dalam melunasi kewajiban jangka pendeknya melalui kas yang tersedia. Semakin tinggi tingkat likuiditas akan menunjukkan bahwa perusahaan tersebut memiliki kemampuan yang tinggi dalam menyelesaikan kewajiban jangka pendeknya. Namun di sisi yang lain, jika tingkat likuiditas tinggi yang ditunjukkan melalui kas dan setara kas yang besar akan memberikan sinyal kepada investor bahwa terdapat dana kas yang menganggur 
Jurnal Ilmu Ekonomi \& Sosial, Vol.11, No.2, Oktober 2020; 92 - 101

p-ISSN: 2085-8779 e-ISSN: 2354-7723

http://ejournal.unmus.ac.id/index.php/ekosos

DOI : $10.35724 /$ jies.v11i2.2754

di perusahaan tersebut. Dengan tingginya dana kas yang dimaksud akan mengakibatkan perusahaan tidak dapat secara optimal untuk memanfaatkan dana tersebut. Peluang investasi yang lain dapat dilakukan oleh manajemen perusahaan dalam meningkatkan nilai perusahaan melalui dana yang tersedia, namun karena dana tersebut dipersiapkan untuk melunasi kewajiban jangka pendeknya maka kesempatan investasi tersebut dapat hilang.

Berbeda dengan penelitian terdahulu yang telah dilakukan oleh Hasania, Sri Murni dan Mandagie [7], serta penelitian yang pernah dilakukan oleh Uttari dan Yadnya [9] yang masing-masing menunjukkan hasil penelitian bahwa likuiditas berpengaruh positif signifkan terhadap nilai perusahaan. Pada penelitian ini, diperoleh hasil bahwa likuditas perusahaan pada perusahaan Properti, Real Estate dan Konstruksi Bangunan, tidak memberikan pengaruh terhadap nilai perusahaan. Penelitian ini sejalan dengan penelitian yang telah dilakukan oleh Lumoly, Murni dan Untu [10] yang menunjukkan bahwa likuiditas tidak berpengaruh terhadap nilai perusahaan pada perusahaan Logam dan Sejenisnya yang terdaftar di BEI periode tahun 2013-2017.

\section{Pengaruh profitabilitas terhadap nilai perusahaan}

Dari hasil uji statistic menunjukkan bahwa nilai signifikansi untuk variabel profitabilitas adalah 0,003 <0,005 dengan nilai t-hitung sebesar 3,329 > t-tabel sebesar 2,079. Hal ini berarti bahwa profitabilias perusahaan berpengaruh positif signifikan terhadap nilai perusahaan pada perusahaan Properti, Real Estate dan Konstruksi Bangunan yang terdaftar di LQ45 periode 2015-2018.

Profitabilitas pada penelitian ini diproksikan melalui return on asset. Proksi ini menunjukkan kemampuan perusahaan dalam menghasilkan laba dengan semua aktiva yang dimiliki oleh perusahaan. Semakin tinggi tingkat profitabilitas melalui nilai ROA tersebut maka semakin besar tingkat laba yang dihasilkan oleh perusahaan melalui aktiva yang dimilikinya. Profitabilitas yang tinggi dapat mencerminkan tingkat prospek perusahaan di masa mendatang akan semakin baik. Hal ini kemudian disusul oleh persepsi investor yang semakin baik sehingga nilai perusahaan akan menjadi tinggi.

Penelitian ini sejalan dengan penelitian terdahulu yang dilakukan oleh Permana dan Rahyuda (2019) [11] serta Hasania, Sri Murni dan Mandagie [8] yang menunjukkan hasil penelitian bahwa secara parsial profitabilitas berpengaruh positif signifikan terhadap nilai perusahaan. Penelitian senada juga telah dilakukan oleh Indriyani [12] serta Gultom, Agustina dan Wijaya [13] yang menunjukkan hasil bahwa secara parsial, profitabilitas berpengaruh positif signifikan terhadap nilai perusahaan. Ignatius Leonardus Lubis, Bonar M Sinaga dan Hendro Sasongko [14] hasil penelitian menyatakan bahwa return on equity (ROE) berpengaruh positif dan signifikan terhadap PBV ROE dapat dipakai sebagai 
prediktor dalam memprediksi tentang nilai perusahaan. Ngurah Dharma dan Vivi Lesstari [15] Likuiditas berpengaruh positif dan signifikan terhadap nilai perusahaan.

\section{Likuiditas dan profitabilitas berpengaruh secara simultan terhadap nilai perusahaan}

Secara statistic diperoleh nilai F-hitung sebesar 5,787 > F-tabel 3,47 dengan tingkat signifikansi sebesar 0,010<0,05. Hasil ini menunjukkan bahwa variabel likuiditas dan variabel profitabilitas berpengaruh secara signifikan terhadap nilai perusahaan. Pada dasarnya, investor akan memberikan penilaian yang baik pada perusahaan yang mempu menyelesaikan kewajiban perusahaan dan juga mampu menghasilkan laba pada periode yang sama. Melalui tingkat likuditas yang tinggi, perusahaan mampu membayar kewajiban jangka pendeknya pada saat jatuh tempo. Sementara itu, profitabilitas yang tinggi akan memberikan gambaran tentang kemampuan perusahaan dalam menghasilkan laba melalui aktiva yang dimiliki.

Persepsi investor terhadap perusahaan akan menjadi baik tidak hanya karena adanya gambaran kemampuan perusahaan dalam menyelesaikan kewajibannya melainkan juga didukung oleh kemampuan perusahaan dalam menghasilkan laba melalui aktiva yang dimiliki. Sehingga melalui variabel likuiditas dan profitabilitas, nilai perusahaan dapat menjadi lebih baik di mata investor.

\section{KESIMPULAN}

Mengacu dari pembahasan maka dapat disimpulkan Likuiditas perusahaan tidak berpengaruh terhadap nilai perusahaan pada perusahaan Properti Real Estate dan Konstruksi Bangunan yang terdaftar di LQ45 periode 2015-2018. Profitabilitas perusahaan berpengaruh positif dan signifikan terhadap nilai perusahaan pada perusahaan Properti, Real Estate dan Konstruksi Bangunan yang terdaftar di LQ45 periode 2015-2018. Likuiditas dan profitabilitas perusahaan secara simultan berpengaruh signifikan terhadap nilai perusahaan pada perusahaan Properti, Real Estate dan Konstruksi Bangunan yang terdaftar di LQ45 periode 2015-2018.

Sehingga disarankan sebelum melakukan investasi, investor disarankan untuk tetap memperhatikan tingkat likuidtias perusahaan namun tidak mengabaikan secara terpisah tingkat profitabilitas perusahaan. Hal ini dimaksudkan karena melalui rasio profitabilitas perusahaan, investor dapat memperoleh gambaran tentang kemampuan perusahaan dalam menghasilkan laba melalui aktivanya, sementara pada kesempatan yang sama, rasio likuiditas dapat memberikan gambaran kemampuan perusahaan dalam melunasi kewajiban jangka pendeknya melalui kas dan setara kas yang dimiliki. 
Jurnal Ilmu Ekonomi \& Sosial, Vol.11, No.2, Oktober 2020; 92 - 101

p-ISSN: 2085-8779 e-ISSN: 2354-7723

http://ejournal.unmus.ac.id/index.php/ekosos

DOI : $10.35724 /$ jies.v11i2.2754

Bagi pihak manajemen yang mengelola sumber daya perusahaan dan agen bagi pemilik perusahaan, agar tetap memperhatikan tingkat likuiditas perusahaan utamanya dalam hal dana kas yang ada pada perusahaan. Dana kas yang ada pada perusahaan diharapkan berada pada titik yang optimal sehinggga tidak ada dana yang menganggur jika berlebihan atau sebaliknya, terjadi kekurangan dana untuk menyelesaikan kewajiban perusahaan.

Bagi peneliti yang akan datang diharapkan menambah variabel lain yang tidak dimasukkan ke dalam penelitian atau melakukan modifikasi terhadap model penelitian yang telah dilakukan.

\section{DAFTAR PUSTAKA}

[1] Sofyan Syafri Harahap, "Analisis Kritis atas Laporan Keuangan", Jakarta Penerbit PT. Raja Grafindo Persada, 2008.

[2] Kasmir dan Jakfar, "Studi Kelayakan Bisnis. Edisi Revisi", Jakarta Penerbit Kencana, 2012.

[3] Wild, Subramayam dan Halsey, "Analisis Laporan Keuangan, Edisi Kedelapan", Diterjemahkan oleh: Yanivi S. Bachtiar dan S. Nurwahyu Harahap, Jakarta Penerbit Salemba Empat, 2005.

[4] I. S. K. Budiman, "Analisis Hubungan Profitabilitas dengan Harga Saham Sektor Usaha Makanan dan Minuman di Bursa Efek Indonesia", Jurnal The Winner, vol. 8, no. 1, Maret: 1-23. 2007.

[5] Van Horne James C dan John M. Wachowicz, “Prinsip-prinsip Manajemen Keuangan, Edisi Kedua Belas", Jakarta Penerbit Salemba Empat, 2005.

[6] Ali Arifin, "Membaca Saham Panduan Dasar Seni Berinvestasi dan Teori Permainan Saham. Kapan Sebaiknya Membeli, Kapan Sebaiknya Menjual", Yogyakarta Penerbit Andi, 2007.

[7] Nur Indriantoro dan Bambang Supomo, "Metodologi Penelitian Bisnis, Untuk Akuntansi dan Manajemen. Edisi 1", Yogyakarta Penerbit BPFE, 2002.

[8] Z. Hasania, Sri Murni dan Mandagie, "Pengaruh Current Ratio, Ukuran Perusahaan, Struktur Modal dan ROE terhadap Nilai Perusahaan pada Perusahaan Farmasi yang Terdaftar di Bursa Efek Indonesia Periode 2011-2014", Jurnal Berkala Ilmiah Efisiensi, vol. 16, no. 03, 2016.

[9] Ida Ayu Sri Uttari dan I Putu Yadnya, "Pengaruh Likuiditas dan Struktur Modal terhadap Kebijakan Dividen dan Nilai Perusahaan (Studi pada Perusahaan Manufaktur yang Terdaftar di Bursa Efek Indonesia)", E-Jurnal Manajemen Unud, vol. 7, no. 6. ISSN: 2302-8912, 2018.

[10] Selin Limoly, Sri Murni, dan Victoria N. Untu, "Pengaruh Likuiditas, Ukuran Perusahaan dan Profitabilitas terhadap Nilai Perusahaan (Studi pada Perusahaan Logam dan Sejenisnya yang Terdaftar di BEI)", Jurnal EMBA, vol. 6, no. 3. ISSN: 23021174, 2018. 
[11] A. A. Ngr Bgs Aditya Permana dan Henny Rahyuda, "Pengaruh Profitabilitas, Solvabilitas, Likuiditas dan Inflasi terhadap Nilai Perusahaan", E-Jurnal Manajemen Unud, vol. 8, no. 3. ISSN: 2302-8912, 2019.

[12] E. Indriyani, "Pengaruh Ukuran Perusahaan dan Profitablitas Terhadap Nilai Perusahaan", Jurnal Ilmu Akuntansi, vol. 10, 2017.

[13] R. Gultom, Agustina dan S.W. Wijaya, "Analisis Faktor-faktor Yang Mempengaruhi Nilai Perusahaan pada Perusahaan Farmasi di BEI", Jurnal Wira Ekonomi Mikroskill, vol. 3, no. 01, 2013.

[14] Ignatius Leonardus Lubis, Bonar M Sinaga H S 2017 Pengaruh Profitabilitas, Sruktur Modal, Dan Likuiditas Terhadap Nilai Perusahaan J. Apl. Bisnis Dan Manaj. 3

[15] AA Ngurah Dharma Adi Putra P V L 2016 Pengaruh Kebijakan Dividen, Likuiditas, Profitabilitas Dan Ukuran Perusahaan Terhadap Nilai Perusahaan E-Jurnal Manaj. Unud 5 4044-70 